\title{
Information actions in science and technology: institutionalities, agencies and subjects ${ }^{1}$
}

\author{
Rodrigo Rabello
}

\begin{abstract}
Doutor em Ciência da Informação pela UNESP.Pós-doutor em Ciência da Informação pelo IBICT. Realiza estágio de pós-doutorado (Bolsa PNPD/Capes) na UnB
\end{abstract}

http://dx.doi.org/10.1590/1981-5344/2483

Considering the influence of new agency forms intervention and interaction among subjects - in the context of information intermediation, we aim to approach information actions in Science and Technology (S\&T) taking into consideration the institutionalities involved. For such, we assume there is an influence of a theoretical model emerging in Information Science (IS) regarding current inventive and interactive form propitiated by the Web. The text is structured in two central topics bringing: i) theoretical and epistemic constructions of the "information action" concept; and ii) a certain interpretation oriented by the "informational action in S\&T" construct, taking as its object the actions performed by IBICT (Brazilian Institute for Information in Science and Technology), directed towards excellence in information. Finally, we discuss how limitations of the "systemic model" propitiate the construction of new study objects in the model emerging in IS from theoretical innovations and counterpoints thoughts facing the diverse forms of information action, considering, for instance, the action of subjects on what concerns the validation of information in the current scenery of institutional intermediation.

\footnotetext{
${ }^{1}$ This text is part of the results from the post-doctorate research "Usuário, informação e ciência e tecnologia: aspectos comunicativos e institucionais em um modelo sociotécnico emergente" concluded in 2012 at IBICT, supervised by Prof. Dr. Maria Nélida González de Gómez. The research kept its connection with the investigation on the theme "User Studies", inserted in the institutional project "Pesquisa e Desenvolvimento de Tecnologias da Informação e da Comunicação para Consolidar a Sociedade da Informação e do Conhecimento" (2011-2013), performed at IBICT's "Programa de Capacitação Institucional" (PCI/IBICT). It was funded by Conselho Nacional de Desenvolvimento Científico e Tecnológico (CNPq). Individual process: 301053/2011-1.
} 
Keywords: Information actions; Information in science and technology; Information Science; Instituto Brasileiro de Informação em Ciência e Tecnologia.

\section{Ações de informação em ciência e tecnologia: institucionalidades, agências e sujeitos}

Considerando a influência das novas formas de agência intervenção e interação de sujeitos - no contexto da intermediação da informação, objetiva-se abordar ações de informação em ciência e tecnologia (C\&T) à luz de institucionalidades envolvidas. Para tanto, considera-se como pressuposto a influência de um modelo teórico que emerge na Ciência da Informação (CI) em contraponto a um modelo denominado de "sistêmico", tendo em vista as atuais formas interventivas e interativas propiciadas com a Web. O texto está estruturado em dois tópicos centrais que trazem: $i$. construções teóricas e epistêmicas do conceito "ação de informação"; e ii. interpretação particular orientada pelo construto "ação de informação em C\&T", tomando como objeto ações realizadas pelo Instituto Brasileiro de Informação em Ciência e Tecnologia (IBICT), direcionadas a excelência da informação. Ao final, discorreu-se sobre como as limitações do "modelo sistêmico" têm propiciado a construção de novos objetos de estudo no modelo que emerge na CI, a partir de contrapontos e inovações teóricos pensados diante das diversificadas formas de ações de informação, considerando, como exemplo, a atuação dos sujeitos no que concerne à validação da informação no cenário contemporâneo de intermediação institucional.

Palavras-chave: Ações de informação; Informação em ciência e tecnologia; Ciência da Informação; IBICT.

Recebido em 10.07.2015 Aceito em 03.11.2015

\section{Introduction}

This paper brings results on the reflection on information actions in Science and Technology (S\&T) performed during the post-doctorate internship at Instituto Brasileiro de Informação em Ciência e Tecnologia (IBICT = Brazilian Institute for Information in Science and Technology) from 2010 to 2012. Part of these reflections constituted the 
communication presented at XIV Encontro Nacional de Pesquisa em Ciência da Informação.

The professional experience motivating this investigation took place while gathering information on users' satisfaction in the institution, aiming towards improving information services and products offered. This initiative used semi-structured interviews, questionnaires and usability analyses of service and product websites. Fifteen products and information services were analyzed ${ }^{2}$ from the assumption of heterogeneity of the information user community in S\&T and the diversity of services and products made available online by IBICT.

While developing this research, certain aspects stood out. One of them refers to the communicative context in which there was an attempt to establish dialogue between managers of products and services studied and the user community participating as partners and collaborators of the institution. IBICT lacked spaces of this nature, given the innovative character of the study.

The experience instigated comprehension of the process of change in attitude of that institution concerting the exploration of new ways to relate with society. One highlighted aspect concerns new means for interaction, access and use of information regarding the World Wide Web (WWW or simply Web). The Web's impact on institutions intermediating information and in various professional and everyday life issues is currently undoubted.

In this context, it is possible to observe that the new emerging scenery has influenced the design and management of information systems, as well as propitiated reflections on institutional actions. Such changes can be noted in the ambit of information professionals' actions. The intended control of such professionals over who accesses and uses information was modified or questioned substantially from this new scenery. An "unplanned audience" emerges from this context that cannot be completely anticipated or foreseen by public or private institutions, as their function regards information intermediation.

The idea of an "unplanned audience" in the Web does not apply to the case of large corporation economic interests and/or political and economic interests in central countries of capitalism. Recent facts corroborate the possibility of anticipations or global registries of information use going around the Web. In 2013, the system administration and former NSA analyst in the USA, Edward Joseph Snowden, revealed to the world on publications on The Guardian and The Washington Post, practices of spying performed by the agency in communications and information transit in the web in various countries,

\footnotetext{
${ }^{2}$ A methodology for studies on use and usabilities was elaborated (ROCHA; SOUSA, 2011) and applied (RABELLO; CAIADO, 2014) in the following information services and products from IBICT: magazines Ciência da Informação, Liinc em Revista and Inclusão Social, Sistema Eletrônicco de Editoração de Revistas (SEER - Electronic System for Editing Magazines), SEER Incubator (INSEER), IBICT Library, Brazilian Digital Library for Theses and Dissertations (BDTD), National Collective Catalogue for Serial Publications (CCN), Bibliographical Commutation Program (COMUT), IBICT Portal, Digital Inclusion Portal, Digital Inclusion Map, CanalCiência, Brazilian Service for Technical Responses (SBRT) and Evaluation of Life Cycle of Productive Systems and Products (ACV).
} 
especially in Europe and Latin America, using computer software, "bugs" and interceptions. In spied countries, including Brazil, they investigate the collaboration of large companies such as Google, Yahoo!, Facebook, Microsoft, Skype, YouTube, AOL and Apple, among others, possibly collaborating to provide information of their users to NSA.

In the case of IBICT, which is not part of the abovementioned exception, the broadening of information user public and the recurrent "unplanned audience" took place not only by actions in the Web, but also by the widening of action focus of the Institute in the field of scientific communication, with its effort, for instance, in promoting "open access". Furthermore, IBICT has been complementing the traditional versant towards scientific communication making information sources available on the Web on social inclusion to digital means and bringing subsidies to productive sectors striving in developing or using technological innovations.

From a theoretical point of view, certain questions arose as discussions in literature on Information Science (IS) echoed over changes in actions from information intermediating institutions, in this case, focusing on IBICT, thus making it a relevant study object, as it is an institution intermediating information acting as a research unit (RU) in the Ministry for Science, Technology and Innovation (MCTI = Ministério da Ciência, Tecnologia e Inovação), being attributed a representative part of information actions in S\&T in this Ministry.

Hence, this research aims to identify and/or propose theoretical constructs concerning information actions in information intermediating institutions in S\&T from the concrete case of IBICT. Specifically, the aim is to appreciate theoretical elements concerning new forms of intervention and informational interaction of the subjects with the aforementioned institutions, stemming from the hypothesis of influence of such theoretical aspects leading towards a new thought, for instance, on criteria for excellence in information on S\&T from a point of view of the different contexts of information validation.

This paper is structured in central topics. In the first one, the first theoretical and epistemic constructions are presented for the approach here employed - "information action" - as well as theoretical-conceptual variables involved. In the second one, we provide evidences for theoretical-conceptual elements allowing an outline of a particular interpretation guided by the concept of "information action in S\&T".

\section{Information actions}

The sense of information actions employed here was influenced by the construct proposed by Gernot Wersig and Gunther Windel (1985) and by the reinterpretation and adaptation of the concept performed by Maria Nélida González de Gómez (1999) ${ }^{3}$. It is possible to

\footnotetext{
3 The concept of "information action" was referred to before in studies such as González de Gómez (2004), Fernandes (2011) and Freire \& Freire (2013), among others.
} 
observe, in both delimitations, the transition of a cognitive perspective towards a social or pragmatic one.

The conception of information actions by Wersig \& Windel (1985) was originally proposed as an alternative to the normative behavioral approach, which disregards the relation of subjective context with the facts of everyday life, as well as social, economic and cultural factors involved. Still, the action, in this case, would be made a tool to resolve issues, i.e. to solve situations of need for information, considering subjective and tool aspects in the individual plan, rather than social ones.

This conception stems from certain aspects of "communicative action theory" by German philosopher Jürgen Habermas, as the paradigm of informational action proposed by the authors draws closer to the model of "medium-end" tool actions incorporating elements of a singular pragmatic approach, considering the relation between action states for treatment and troubleshooting.

A new reading on González de Gómez (1999) focuses on information actions in the habermasian communicative ambit itself, aimed towards the mutual understanding of the participants of the action. It also transcends the governmental and state sphere in an information policy conception involving a network of human and non-human actors, forming what Bernard Frohmann (1995), in a Foucault-based interpretation, called "information regimes". González de Gómez (2003, p. 61) interprets the "information regime" as:

[...] the means of informational production dominant in a social formation, which defines who the subjects, organizations, rules and informational authorities are and what preferential resources and means of information, patterns of excellence and models of organization, interaction and distribution are in action for a given time, place and circumstance, according to certain cultural possibilities and certain power relations. An "information regime" unfolds soon in a more or less stable group of formal and informal networks in which information is generated, organized and transferred from different producers, from many and various means, channels and organizations, to different addressees or recipients of information, be them specific users or wide publics.

In this context, informational testimonies or values, facing various layers and selection and decision acts would be constituted by overdetermination of the "structural indecibility" of information. The unpredictability of a structure at first comes from elective acts of individuals or social groups aiming towards making decisions, be they explicit and formal or tacit and informal. In addition, information actions, according to González de Gómez (1994, p. 4, italics by the author), "[...] stipulate what is the case in which information is the case." 
In addition to the selective character performed by cognoscenti and social actors, by epistemic communities and/or among networks and systems, actions can be analyzed from variables deduced by their stratified character. Three significant strata González de Gómez (1999, p. 9) identified are:

a)"informational or semantic stratum" - proposed before an interpretative flexibility whose variables are found in the motivations of practices, idea exchanges, disagreements and disputes, influencing, for instance, the production of theoretical and technical models and of technologies. Such flexibility would pass by contemporary forms of "information regimes" which, in theory, condition actions to inform and seek information, finding locus in practical-discursive networks guided by validation criteria in norms and rules, getting to justification of information artifacts;

b) "information devices stratum" - assumed in documentation gathered beforehand which brings the memory of information actions, as well as tools laid out by the cultural ambient. This stratum would make it possible to create tools and means for its relation and availability in face of "informational artifacts" (tangible, material dimension). Furthermore, the "devices" can be associated with the concept of "metainformation". While "metainformation", conducted by rules, would structure information, the "device" would perform a similar function to the construction of "networks", overdetermining them and specifying them to particular characteristics;

c)"metainformational or infrastructural stratum" - "[...] where rules are established for their interpretation and distribution, specifying the context where a piece of information makes sense." (GONZÁLEZ DE GÓMEZ, 1999, p. 9). They are rules and regulations comprised of various documental practices or instances whose actions constitute mechanisms of conformation and control.

From these strata, one can infer that Wersig and Windel could not rid themselves completely from the cognitivist perspective, but advanced presenting a situational approach as they propose a study of "action states." Conversely, González de Gómez's study acknowledges such advancements and proposes a concept for "information action" comprehending the search for mutual understanding in the subjects' relations, i.e. in a social context comprised of selective and stratified actions. It considers, for example, social rules strata, as well as those of testimonial attributes and information evidence. 
The context of social interaction defended by González de Gómez benefits and acquires new characteristics from adding the notion of network. In this perspective, the network would be the relational structure lacking a center and assumes more than one line connecting to the same point, in something that would be easier to imagine, for example, if compared to the structure of a cobweb or chainmail, in multi-scale compositions.

The broad sense of network understood by González de Gómez can be, at a certain rate, outlined within institutional terms from Bruno Latour's conception of "calculus center". Latour makes an analogy with cartographic knowledge to demonstrate how using research tools, which he calls "metainformational maps", can be important for conquering new knowledge.

The superposition of tools and results in search of central characteristics for the analysis of phenomena would comprise the cartographic procedure. "Freezing" a given layout of a network would be necessary to compare different pieces of information. Comparing places and superposing one map over another would make it possible to visualize the circulation of phenomena before a "safe haven" of registries. So the "calculus center" would be a privileged place allowing juxtaposition and analysis of various maps.

Digital technologies increased the broadening of the "calculus center", facing the interconnectivity in network. Computers have made it possible, in the words of Latour \& Hermandt (2004, p. 49), "[...] to move around, relink, combine and translate designs, texts, photographs and calculi now still physically separated."

One can infer that is it possible to observe the influence of information actions in the ambit of institutions intermediating information from a perspective of interconnectivity. The institution to be the object of analysis in this study is the one working with systems intermediating information in S\&T. The intermediation is operationalized in face of "metainformation" and "metainformational maps" in S\&T.

"Metainformation" can be understood as an input or product of organization tools to access, retrieve and use information. "Metainformation" subsides the work of information professionals in what concerns the construction of systems, databases and information sources, embodying the object of intermediation and constituting, furthermore, the input for technology transference

In addition to the function of subsiding the production of knowledge in the "calculus centers", the "metainformational maps" can be made tools for monitoring and controlling information in S\&T aiming towards providing with subsidies for the proposition of information policies and, also, bringing the panorama of institutional organization of science and intermediating information systems.

The intermediating information systems, on the other hand, constitute specific institutional spaces where the "scientific intelligence" acts. "Scientific Intelligence" refers to specialists, scientists and managers acting in those systems intermediating information, aiming towards the 
performance and efficacy of science. Such spaces and actors historically bring new fundaments of rationality to contemporary forms of production, transmission, sharing and appropriation of knowledge in S\&T.

\section{Information actions in S\&T}

IBICT is a public institution intermediating information that operates "metainformation" in systems as a means to perform its finalistic actions of treatment and organization of information for dissemination, access and retrieving information in science, technology and innovation. The Institute, since its foundations, has found in IS theoretical and methodological subsidies to fundament its actions.

Guided by the mission of promoting "[...] competence, development of resources and information infrastructure in science and technology for the production, socialization and integration of scientific-technological knowledge" (BRASIL, 2012), IBICT has been adapting to contemporary sociotechnical transformations in the scenery of information, promoting strategic actions in S\&T in Brazil.

With approximately 30 institutional initiatives distributed among programs, products and information services, a diverse repertoire of actions can be seen promoted by IBICT, passing by actions in teaching and research in IS, dissemination and providing society with information, as well as making information technology transference available to institutions (BRASIL, 2012).

As fundament to IBICT's actions spectrum, IS theoretical constructions help understanding information settings in S\&T facing information and communication technologies that made it possible, especially from the 1990s, to collaborate with and share intellectual production in network.

This integration changed the research work relations, altering actions in producing knowledge, in the behavior of use of scientific literature, in the means of access to information, as well as in the relation with tools and spaces destined to producing knowledge.

In addition, the orientation of the research towards troubleshooting, in a transdisciplinary plan, benefited from information and communication technologies, as they made intellectual sharing and integration easier among knowledge domain actors guided by converging finalities, making previous disciplinary strictness notions more flexible (GONZÁLEZ DE GÓMEZ, 2003).

Information, as González de Gómez (2000) points out, constitutes a phenomenon to be controlled and monitored when making informational decision in the institutional ambit. In this context, the "control action" is dedicated to information to transform and the "monitoring action" to the information to plan.

Considering the identification of information actions in IBICT and taking for a fundament the different modalities of "metainformation", it becomes pertinent to picture it from the perspective of control actions and monitoring resulting in the consolidation of dissimilar forms of interaction 
between institution and society, in the case of IBICT, guided by macroprocesses.

Based on IS assumptions, in addition to the macroprocess "research and teaching" (BRASIL, 2014), IBICT's finalistic actions are also directed to the macroprocess "information management" consisting in guaranteeing or propitiating, thoughtfully, the intermediation of information and transferring technology facing the processes of treatment, organization and representation of information, with which one seeks to control and standardize information, systems and technologies, aiming towards its dissemination (RABELLO; CAIADO; ARAÚJO, 2013).

The information, object of standardization, is, in the end of the chain or flow of information, made available to society facing a policy of open access. Thus implementing such policy, standardized systems and technologies are made available to partner institutions by means of a particular policy of technology transference. In this macroprocess, disseminating information and transferring systems and technologies can be categorized by the product binomial and information service.

Information products are concrete informational devices - including systems and technologies - resulting from technical-operational processes guided by information management towards information in S\&T. Such products can be better visualized in information sources, technical works and publications (books and journals), in digital or hard copies, resulting from studies in S\&T. Included are manuals, methodologies, prospection inputs, and also the result of the effort in translation, customization, maintenance and developing software and information systems, as well as websites and portals (RABELLO; CAIADO, 2014).

Information services are means by which products are intermediated - disseminated or transferred to society - being shaped or guided by their diversified nature. Services can be offered locally at IBICT's facilities, or at long distance, or online, by means of telephone or websites. Such services unfold in services of technological information, access and distribution of databases, cooperation for access to registries and documents, documentation and bibliographical commuting, referential information, technical response, information for industries, and information for digital inclusion (RABELLO; CAIADO, 2014).

Hence, IBICT has acted in MCTI creating, managing and making information services and products available, intermediating "scientific intelligence" actions, also in charge of monitoring and controlling information in S\&T. However, IBICT's actions transcend this context as the institution becomes in charge of fomenting information policies.

As observed, towards beyond managing products and services, IBICT is also in charge of making information infrastructures available so as to establish partnerships with other institutions intermediating information. IBICT assumes, furthermore, the function of federal public organ catalyzing and incentivizing information policies. This can be seen, for example, when the institution acts incentivizing policies towards "open access", when it provides infrastructure, enables and gives support to institutions of education and research to feed BDTD (Biblioteca Digital 
Brasileira de Teses e Dissertações = Brazilian Digital Library for Dissertations and Theses), or to create institutional journal portals, facing SEER (Sistema Eletrônico de Editoração de Revistas = Journal Editing Electronic System), or to create and feed institutional containers, among other initiatives.

Considering these particularities, questions arose on what IBICT's main information intermediating actions would be to conflate in performing its finalistic actions. Table 1 helps visualize the "metainformation" relation with IBICT's information actions in S\&T inserted in the context of MCTI.

Table 1 - Information actions and products-input in Science and Technology in the context of IBICT/MBCTI

\begin{tabular}{|c|c|c|c|c|c|c|}
\hline $\begin{array}{l}\text { Actions/ } \\
\text { Product }\end{array}$ & \multirow{2}{*}{\begin{tabular}{l}
\multicolumn{1}{c}{$\begin{array}{c}\text { End- } \\
\text { actions }\end{array}$} \\
dissemina \\
tion, \\
access \\
and \\
retrieving \\
informatio \\
$n$
\end{tabular}} & \multirow{2}{*}{\begin{tabular}{l}
\multicolumn{1}{c}{$\begin{array}{c}\text { Mid- } \\
\text { actions }\end{array}$} \\
- managing, \\
treating and \\
organizing \\
information
\end{tabular}} & \multirow{2}{*}{$\begin{array}{l}\quad \text { Tool } \\
\\
\text { - documental } \\
\text { languages } \\
\text { - theories } \\
\text { and } \\
\text { methodologie } \\
\mathrm{s} \text { in IS }\end{array}$} & \multirow{2}{*}{\begin{tabular}{l}
\multicolumn{1}{c}{ Input } \\
\\
- information \\
concerning \\
information \\
products/serv \\
ices \\
- databases \\
- \\
portals/websi \\
tes
\end{tabular}} & \multicolumn{2}{|c|}{$\begin{array}{l}\text { Products/ } \\
\text { input "metainformation", }\end{array}$} \\
\hline $\begin{array}{l}\text { IBICT } \\
\text { (finalistic } \\
\text { actions) }\end{array}$ & & & & & $\begin{array}{l}\text { - documental } \\
\text { information } \\
\text { - metadata } \\
\text {-tags }\end{array}$ & $\begin{array}{l}\text { - information } \\
\text { products/ser } \\
\text { vices and } \\
\text { programs }\end{array}$ \\
\hline \multirow[t]{2}{*}{$\begin{array}{l}\text { IBICT } \\
\text { (mid- } \\
\text { actions) }\end{array}$} & $\begin{array}{l}\text { obtaining } \\
\text { diagnosis } \\
- \\
\text { managem } \\
\text { ent and } \\
\text { planning } \\
\text { for } \\
\text { technical } \\
\text { units }\end{array}$ & $\begin{array}{l}\text { - managing } \\
\text { and } \\
\text { organizing } \\
\text { information }\end{array}$ & $\begin{array}{l} \\
\text { methodologie } \\
\text { s/tools in } \\
\text { managing } \\
\text { information } \\
\text { and } \\
\text { knowledge }\end{array}$ & $\begin{array}{l}\text { - reports } \\
\text { - publications } \\
\text { (quantitative / } \\
\text { qualitative } \\
\text { data) } \\
\text { - databases }\end{array}$ & $\begin{array}{l}\text {-information } \\
\text { concerning } \\
\text { products/servi } \\
\text { ces } \\
\text { (quantitative/q } \\
\text { ualitative data) }\end{array}$ & $\begin{array}{l}\text { - reports } \\
\text { - process } \\
\text { maps } \\
\text { - manuals } \\
\text { - } \\
\text { publications }\end{array}$ \\
\hline & $\begin{array}{l}\text { - } \\
\text { obtaining } \\
\text { diagnosis } \\
\text { - impact } \\
\text { of use, } \\
\text { resources } \\
\text { and } \\
\text { infrastruct } \\
\text { ure for } \\
\text { informatio } \\
n\end{array}$ & $\begin{array}{l}\text { - managing } \\
\text { and } \\
\text { organizing } \\
\text { information }\end{array}$ & $\begin{array}{l}\text { - information } \\
\text { concerning } \\
\text { products/serv } \\
\text { ices } \\
\text { - theories } \\
\text { and } \\
\text { methodologie } \\
\text { s in IS }\end{array}$ & $\begin{array}{l}\text { - quantitative } \\
\text { data } \\
\text { (metric/statist } \\
\text { ic indicators) } \\
\text { - qualitative } \\
\text { data } \\
\text { - metadata }\end{array}$ & $\begin{array}{l}\text { - diagnosis } \\
\text { map }\end{array}$ & $\begin{array}{l}\text { - reports } \\
\text { - } \\
\text { publications } \\
\text { - databases }\end{array}$ \\
\hline $\begin{array}{l}\text { IBICT / } \\
\text { MCTI }\end{array}$ & $\begin{array}{l}\text { - } \\
\text { obtaining } \\
\text { diagnosis } \\
- \\
\text { following } \\
\text { up } \\
\text { managem } \\
\text { ent, } \\
\text { planning }\end{array}$ & $\begin{array}{l}\text { - managing } \\
\text { and } \\
\text { organizing } \\
\text { information }\end{array}$ & $\begin{array}{l}\text { - PDU/TCG } \\
\text { (IBICT) }\end{array}$ & $\begin{array}{l}\text { - quantitative } \\
\text { data } \\
\text { (metric/statist } \\
\text { ic indicators) } \\
\text { - qualitative } \\
\text { data } \\
\text { - metadata }\end{array}$ & $\begin{array}{l}\text { - diagnosis } \\
\text { map }\end{array}$ & $\begin{array}{l}\text { - reports } \\
\text { - } \\
\text { publications } \\
\text { - databases }\end{array}$ \\
\hline
\end{tabular}




\begin{tabular}{|c|c|c|c|c|c|c|}
\hline & $\begin{array}{l}\text { and } \\
\text { productivit } \\
\text { y (UP) }\end{array}$ & & & & & \\
\hline MCTI & $\begin{array}{l}\text { obtaining } \\
\text { diagnosis } \\
- \\
\text { informatio } \\
\mathrm{n} \text { on S\&T }\end{array}$ & $\begin{array}{l}\text { - managing } \\
\text { and } \\
\text { organizing } \\
\text { information }\end{array}$ & $\begin{array}{l}\text { - PDU/TCG } \\
\text { (UP, } \\
\text { including } \\
\text { IBICT) } \\
\text { - information } \\
\text { provicded or } \\
\text { published by } \\
\text { other organs } \\
\text { (public or } \\
\text { private) }\end{array}$ & $\begin{array}{l}\text { - quantitative } \\
\text { data } \\
\text { (metric/statist } \\
\text { ic indicators) } \\
\text { - qualitative } \\
\text { data } \\
\text { - metadata }\end{array}$ & $\begin{array}{l}\text { - diagnosis } \\
\text { map }\end{array}$ & $\begin{array}{l}\text { - reports } \\
\text { - } \\
\text { publications } \\
\text { - databases }\end{array}$ \\
\hline
\end{tabular}

Source: Adaptation of the Table elaborated by RABELLO (2012).

Aiming towards diffusion, access and retrieval of information in S\&T, IBICT's finalistic actions include "mid-actions" of treating and managing information and also with documental languages, methodologies and theories in IS. The main input is information concerning information services, products and programs. Other "midactions" concerning finalistic actions consist in diagnosing:

a)technical units management and planning - performed by managers and/or planning sector so as to obtain data on the dynamics, workings and results obtained from management processes;

b)impact of information infrastructure use - generally headed by managers facing the performance of researches that can culminate, for example, in reports and publications;

c)monitoring MCTI productivity - IBICT and other research units must account for their commitments in management to MCTI, guided by metric indicators of following up/productivity. This diagnosis is required by MCTI to research units by means of tools such as Plano Diretor da Unidade (PDU = Unit Director Plan) and the Termo de Compromisso e Gestão (TCG Management and Commitment Term). PDU is a an official document bringing the projection and commitment of the research unit before MCTI to act in lines of action and strategic axes so as to operationalize projects and programs in a fiveyear period (BRASIL, 2010). TCG, on the other hand, consists in the registry of commitment of the research unit before MCTI to formally establish goals of annual development to be reached during the agreed period (BRASIL, 2011);

d)information on S\&T - MCTI has data provided by all research units, including information on other public and private institutions, both governmental and non-governmental, to consolidate the "state of the art" of S\&T in Brazil. 
Both in actions of productivity monitoring and in diagnosing, "metainformational maps" are produced, for instance, in technical reports and in publications.

As observed, IBICT's finalistic actions mostly aim towards solving problems of investigating and intermediating information, i.e. they are directed to subjects performing researches or institutions intermediating information. IBICT's "user community" corresponds to a wide specter of users transcending traditional ones, i.e. research aspirants (students) and researchers, or partner institutions. Also citizens who can use products and services from IBICT are included here, so as to reach varied finalities, such as information for social and digital inclusion or information for innovation.

The user of information services and products, in the condition of knowledge producers, has a social function inherent to his/her work. The social figure of the researcher, in this case, is emblematic, as his/her action passes by the process of knowledge production, in the form of communication and publication of results and expected consequences of the investigation products.

It does not suffice for the researcher to produce quality knowledge with social utility. Such knowledge must also be transmitted by channels validated by the scientific community. The differential of such channels would be acknowledgeable and justifiable excellence criteria. As González de Gómez (2002; 2003) explains, excellence criteria for information on S\&T are assumed in the so-called "science social contract". From the perspective of such a contract, she states that excellence criteria for information on S\&T would be guided by principles of "articulation", "convergence" and "transparency".

The "articulation" refers to the relation between the State and society. In this articulation, one seeks to reach a "common interest", for example, to create "specialized functional structures" of information on S\&T. The creation and maintenance of IBICT as an institution for mediating information would not be possible without an articulation between the State and sectors from society.

"Convergence" refers to the "practical-contractual" relation, for instance, between the user community and the institution providing information services and products. In this case, managers' actions are expected to converge with the user community's expectations; in addition, information is supposed to be made available, and the means of intermediation and technologies to be transferred should be consistent and up-to-date. Furthermore, technological resources of the institution intermediating information are expected to be compatible with the technologies available, making it possible to the user community to access and retrieve available information more easily.

The last principle - "transparency" - refers to the search for quality in processes, means and contents made available. In addition, transparency is related with publicizing the institution's internal operations, i.e. it refers to the transparency of "backstage" information actions. 
One can infer that the difficulty of transparency in the relation among public institutions intermediating information and society has led them to propose specific approaches to study the situations of need of the user community of information services and products from the perspective of the institutional mission.

Indeed, even leaving aside the previously systematized theoretical fundaments, one can still deduce that the current informational context itself may have influenced IBICT to give a significant step from the attempt of overcoming a strictly "systemic" action model towards a more open interactive and dynamic model in emergence. The setting and differentiation between the models were approached more thoroughly in Rabello (2013a).

The "systemic model" is understood to be a theoretical space considering the indispensability of the information system whose main actor is the professional, i.e. the one who designs and manages the system, dislocating the subject who uses information from the system or the systems itself to a condition of passiveness and little interference. There is greater value, in this strict conception, in the objective character of information, something that characterizes, according to Capurro (2003), the "physical or objective" paradigm.

A relative widening of the "systemic model" was identified in the end of the 1970s and throughout the 1980s, when Dervin \& Nilan (1986) indicated the appeared of "alternative approaches" in informational behavior studies. The predominance of behavior studies, i.e. subjective aspects of the subjects, was named by Capurro (2003) the "cognitive paradigm." While the focus then was on the system user represented in a qualitative leap towards this strictly "systemic" conception, the indispensability of the system is still part of this conception. Hence, it is inferred that this would be a transitory stage of the "systemic" model towards a theoretical model, here named "emergent sociotechnical" or simply "emerging model."

The "emerging model" would be the one being formed. In this model, the notion of user gives place to a wider conception of subject as it considers his/her interaction with other subjects and observes his/her reflection on information actions; in this latter case, one can consider or dispense the notion of system. What is inferred here is that the "emerging model" can be set in what Capurro (2003) named "social or pragmatic paradigm" of information. This model came to be better observed in IS literature in the late 1990s, with the expansion of the Web and, especially, during the first decade of the new millennium, as it is a moment when the notion of information context started to come to attention (PETTIGREW; FIDEL; BRUCE, 2001; CASE, 2006; COURTRIGHT, 2007; FISHER, JULIEN, 2009; RABELLO, 2013b).

It is possible to infer that the questioning of "systemic" assumptions influenced IBICT to seek new forms of institutional action as it materialized, with the creation of a specific methodology, guidelines for assessing information services and products from the interaction of the 
institute with the user community, mostly comprised by students, researchers and institutions intermediating information.

The book Metodologia para a avaliação de produtos e serviços de informação (ROCHA; SOUSA, 2011) was elaborated aiming to constitute an alternative to assess information services and products, considering the heterogeneity of users of information on S\&T and, in particular, the diversity of the products and services IBICT makes available.

As Rocha \& Sousa (2011, p. 28) explain, triangulating approaches of quantitative and qualitative nature, facing the application of interviews and questionnaires, as well as performing the analysis of usability of websites for products and services, converged to the same end: to offer a tool that makes it possible to obtain "[...] greater consistency and integrity of results from the view of the assessor and s/he who uses it."

Comprising one of the main dimensions of the development of information services and resources, the assessment proposal aimed to help the institution meet the finalities of addressees' information use and appropriation, associating with an organizational learning process. At the end of the study, diagnostics were consolidated from the experiences and expectations of the user community (RABELLO; CAIADO, 2014), obtaining subsidies to improve information services and products. This initiative was in consonance with the principles for excellence in S\&T cast by González de Gómez (2002; 2003).

On the other hand, this initiative points to a complex conjectural framework touching defaced theoretical and institutional aspects in the emerging model. On the possible imbricated phenomena in such institutional and theoretical aspects, three hypotheses have been identified so far regarding the questions that lead to a widening theoretical and practical dialectic:

1) Limitation - information intermediating institutions present an inherent difficulty to distance themselves from a strictly "systemic" model, as they are characterized for operating information intermediating systems. In this case, the conception of system is intrinsic to the notion of institutionalism itself. In theory, the system and its working are limited to the founding principle that justifies and conducts the modus operandi of the institutional act;

2) Counterpoint - researches in the bowl of the still shapeless "emerging model" have been of significant influence to institutions intermediating information questioning, in the theoretical plan, the conceptions considering, for instance, the passive or merely cognitive character of subjects. From there emerges the contradiction of the institution to continue to have as reference a "systemic" modus operandi despite finding limitations in it and, from it, founding actions that come to minimize the apparent mismatch between institutional act and contemporary forms of informational agency, as they are marked by dynamism of intervention possibilities made possible by digital and network technologies; 
3) Innovation - opening the possibility to create new study objects from a broad notion of information and interacting subject and intervener in different forms of information validation. In fact, conceptions of institutionalisms emerge in which different information phenomena are measured under the influence of dissimilar information regimes. Theoretical proposals or syntheses, in this direction, tend to denote themselves as strange to agents of the modus operandi of the intermediating institutions, as they are then founded in assumptions that lead to the need for lenses from a new phenomenology and new institutionalism demands. In addition to the difficulty of overcoming the established informational culture, socially claimed new institutionalisms tend to, furthermore, dismiss theoretical and/or formal concretization fundaments facing the lack of juridical regimes or regulations that support them.

As observed in the case of IBICT, initiatives and attempts of transcendence to resistance and to "systemic" process and theoretical limitation benefit from the theoretical counterpoint and from the innovation that find fertile ground in information studies and their social dimension. One infers that qualitative leaps towards innovation will be reached from the proposition and elaboration of new theoretical frameworks, conceptualizing subjects and new forms of agency and of spaces of interaction, aiming to understand contemporary informational intervention in different institutionalisms, i.e. in dissimilar information regimes.

An example of initiative directed towards innovation touching interaction spaces was mentioned by González de Gómez (2002), as she points to the need for "[...] participation of different actors in translation forums and spaces." She suggests the creation of hybrid forums. As she points out,

Uncertainty situations require, on their own quality, the constitution of hybrid forums, involving specialists, actors implied by the situations, State agencies, private enterprises and social movements: the only option passes by questioning, debate, and reflection processes of argumentation. (GONZÁLEZ DE GÓMEZ, 2011).

IBICT's participation in hybrid forums would be of great contribution since, as observed, it particularizes itself to the other research units of MCTI, considering a central aspect: the particularity of its finalistic actions. In a nutshell, the institution is responsible for articulating or incentivizing information policies, being, thus, responsible for exclusive information services and products in S\&T, something that guarantees its singularity of subjects and collaborating institutions which IBICT has relations.

The communicative spaces propitiated by these translation forums would transcend strict concerns to information transfer chains, i.e. they would go beyond strict concerns on information services and products. 
These places of innovation could propitiate the performance of theoretical and technological prospections, as well as the elaboration of concrete experiences and methodologies aiming to reach, by means of dialogue with different actors, criteria of excellence and strategic information policies.

\section{Final considerations}

Information actions make it possible to reflect on the subjects' actions. This makes room for reframing these actors, considering each in their own role and from strategic positions they occupy in the agency. This perspective allows further questioning of conceptions of strictly "systemic" institutionalities. Indeed, it makes room for questionings directed to theoretical positions that, in a naturalized form, have been disregarding actors or relegating them to the position of supporters.

In other words, the pragmatic dimension of information, in the scenery of information actions, gives privilege to subjects transcending approaches that have been considering users strictly as information containers or their mental structures during the access and use of information, or the mental structures of information professionals, during their actions in management or informational practices.

Adding to this "systemic" dimension, the pragmatic dimension of information has been providing theoretical and practical counterpoints to problematize the actions of information professions in eminently hierarchized contexts, when this professional action is referred by bureaucratic assumptions.

Considering subjects in interaction, apprehended in their communicative and intervening potentialities, intensifies the alternatives of creating new study objects. In this perspective, information actions have brought a different horizon as it points to possible changes of action in information intermediating institutions.

It is assumed that every subject who interacts in the social fabric is forged particularizing him/herself amongst a heterogeneous collective. The subject is shaped, therefore, by institutionalities, positions and conceptions of a world shared or referred collectively, influencing or being influenced by their cognoscibility founded by signs and symbols lived or inscribed in their cultural, social and political heritage, i.e. their historicity.

The habermasian concept of "symbolically structured world of life" is a particular sense of this intersubjective historicity. According to Habermas (2010, p. 20-21), this conformation of the world of life is constituted from the formal pragmatics comprised by communicative acts of intervening actors, i.e. participants interpreting this world in linguistic terms.

The forms of social integration, under this perspective, are conceptually articulated by the vector of action theory, ruling the actors to pursue, facing understanding processes, action objectives guided by their own preferences. Furthermore, this theory considers that social relations 
are regulated by forms of power and market that can reverberate in interaction modes mediated by language.

For these reasons, language constitutes a background for the world of life, passible of differentiation by types of speech act and validation intentions. The determinants in this learning pass by cultural knowledge (schemata passible of consensuality), by social solidarity resources (legitimately ordered interpersonal relations) and by personalization results (specific structures).

This particular conception of subject action in the "symbolically structured world of life" makes room or has been a basis for IS studies considering that subjects validate and judge information not only by its relevance, as Saracevic (2009) stipulates, but for intrinsic aspects that confer them credibility, or that consider, as validation objects, gnosiologic subjects in their cognitive authority, as well as informational indications or products from them (RIEH; BELKIN, 1998; RIEH, 2002; FIGUEIREDO, 2011; GONZÁLEZ DE GÓMEZ, 2011). In this direction, in addition to the contexts of transmission, sharing and appropriation, the contexts of social production of knowledge are also then regarded as analysis objects.

In such contexts, the symbolic structuring space becomes even more complex in face of different supports or ephemeral ambits such as the ones where validation intentions circulate. Among technological ambits, the Web stands out with new forms of experimenting in what regards space-time relation, adding to the possibility of information validation and intersubjective experience exchanges unimaginable before. This channel made it possible to transmit communicative intentions revealing the need for a different phenomenology to conceptualize, for example, new validation concepts.

From the point of view of information intermediating institutions, the interaction between institution and society suggests the need to review or bring new signs to the structuring concept of subject in the condition of actor of the actions. Furthermore, the broadness of objects and places of validation and the expected transparency in the means and forms of communication have brought to our attention the need for new institutional spaces that make it possible to explore interactive and intervening potentialities of subjects in and out of the Web, as well as stimulate investigation of the potential of such actors in the condition of validating agents, despite the need for these institutions to bear with the "systemic" assumptions, to a greater or lesser degree, as observed in the case of the theoretical counterpoint IBICT essayed.

As we know, the constitutive limitation of these institutions makes it difficult to transcend to the vertical hierarchical layout within which systems are kept and managed. The counterpoints and innovations brought in the emerging theoretical model, guided by the social dimension of information and tinted by the unfolding of contemporary notions of network, make room for the study aiming to create places to potentiate and privilege the dialogue between the information intermediating institution and society. 
The pioneering character of theoretical counterpoint experimented with the application of a specific methodology to perform the studies of IBICT's user community is an indication that the potential of such subjects hasn't been taken advantage of by the institute towards a reflection on, for example, excellence criteria for information on S\&T. This initiative teaches that subjects comprising the user community of institutions of this nature should be considered partners for the dialogue and formulation and/or maintenance of information policies, being indispensable, as they constitute the raison d'être of public and private institutions in charge of intermediating or promoting information intermediation to society.

\section{References}

BRASIL. Ministério da Ciência e Tecnologia. Instituto Brasileiro de Informação em Ciência e Tecnologia. [PDU]: Plano Diretor [da Unidade ou] do IBICT: 2011-2015: [planejamento estratégico do IBICT]. Brasília: IBICT, [2010]. 32 p.

BRASIL. Ministério da Ciência e Tecnologia. Instituto Brasileiro de Informação em Ciência e Tecnologia. [TCG]: Termo de Compromisso de Gestão que entre si celebram o MCT e o IBICT. Brasília: IBICT, [2011]. 29 p.

BRASIL. Ministério da Ciência e Tecnologia. Instituto Brasileiro de Informação em Ciência e Tecnologia. Missão. Brasília: IBICT, [2012]. Disponível em: <http://www.ibict.br/sobre-o-ibict/apresentacao > . Acesso em: 14 abr. 2012.

BRASIL. Ministério da Ciência e Tecnologia. Instituto Brasileiro de Informação em Ciência e Tecnologia. [Pesquisa e Pós-graduação]. Brasília: IBICT, 2014. Disponível em: <http://www.ibict.br/capacitacao-eensino>. Acesso em: 25 mar. 2013.

CAPURRO, R. Epistemologia e Ciência da Informação. [S.I.: s.n.], 2003. Disponível em: <www.capurro.de/enancib p.htm>. Acesso em: 30 out. 2005.

CASE, D. O. Information behavior. ARIST, v. 40, p. 293-327, 2006.

COURTRIGHT, C. Context in information behavior research. ARIST, v. 41, p. 273-306, 2007.

DERVIN, B.; NILAN, M. Information needs and uses. ARIST, v. 21, p. 333, 1986.

FERNANDES, G. C. Ações de informação e práticas documentárias como políticas difusas de memória. InCID: R. Ci. Inf. e Doc., v. 2, n. 1, p. 208226, jan./jun. 2011. Disponível em: <http://www.revistas.usp.br/incid/article/view/42342>. Acesso em: 12 out. 2012.

FIGUEIREDO, M. F. Busca e validação da informação imagética na web. 2011. 108f. Dissertação (Mestrado em Ciência da Informação) - Instituto Brasileiro de Informação em Ciência e Tecnologia, Rio de Janeiro, 2011. 
FISHER, K.; JULIEN, H. Information Behavior. ARIST, v. 43, p.317-358, 2009.

FREIRE, I. M.; FREIRE, G. H. A. Ações de informação para o ensino médio no Laboratório de Tecnologias Intelectuais - Lti. MPGOA, v. 2, n. 1, p. 123-137, 2013.2 Disponível em: <http://www.revistas.usp.br/incid/article/view/42342>. Acesso em: 12 dez. 2013.

FROHMANN, B. Taking policy beyond information science: applying the actor network theory for connectedness: information, systems, people, organizations. In: ANNUAL CONFERENCE CANADIAN ASSOCIATION FOR INFORMATION SCIENCE, 23., 1995, Edmond, Alberta. Proceedings... [S.I.: S.n.], 1995.

GONZÁLEZ DE GOMEZ, M. N. O caráter seletivo das ações de informação. Informare, v.5, n.2, p.7-35, 1999.

GONZÁLEZ DE GOMEZ, M. N. La Sociedad del conocimiento. Análise del concepto referente. In: CONTRIBUCIÓN AL DESARROLLO DE LA SOCIEDAD DEL CONOCIMIENTO. Eds.Margarita Almeida de Ascencioet alii. México, UNAM, Centro Universitário de Investigaciones Bibliotecológicas, 2000. 486 p.; p.15-32. Trabalhos apresentados no XVII Coloquio Internacional de Investigación Bibliotecológica.

GONZÁLEZ DE GOMEZ, M. N. Novos cenários políticos para a informação. Ci. Inf., v. 31, n. 1, p. 27-40, jan./abr. 2002.

GONZÁLEZ DE GOMEZ, M. N. As relações entre ciência, Estado e sociedade: um domínio de visibilidade para as questões da informação. Ci. Inf., v. 32, n. 1, p. 60-76, jan./abr. 2003.

GONZÁLEZ DE GOMEZ, M. N. Novas fronteiras tecnológicas das ações de informação: questões e abordagens. Ci. Inf., v. 33, n. 1, p. 55-67, jan./abr. 2004.

GONZÁLEZ DE GOMEZ, M. N. Da validade da informação à validade dos conhecimentos: inventariando recursos, normas e critérios. Rio de Janeiro: PPGCI- IBICT- UFRJ, 16 ago. 2011. 34p. [Projeto de pesquisa apresentado ao CNPq para obtenção de bolsa PQ].

HABERMAS, J. Fundamentação linguística da sociologia. Lisboa: Edições 70, 2010.

LATOUR, B.; HERMANDT, È. Redes que a razão desconhece: laboratórios, bibliotecas, coleções. In: PARENTE, A. Tramas da rede: novas dimensões filosóficas, estéticas e políticas da comunicação. Porto Alegre: Sulina, 2004. p. 39-63.

PETTIGREW, K. E.; FIDEL, R.; BRUCE, H. Conceptual frameworks in information behavior. ARIST, v. 35, p. 43-78, 2001.

RABELLO, R. Usuário, informação e ciência e tecnologia: aspectos comunicativos e institucionais em um modelo sociotécnico emergente. Brasília: IBICT, 2012. [Relatório final de pesquisa de pós-doutorado]. 
RABELLO, R. Noções de usuário em modelos teóricos na Ciência da Informação: do enfoque no sistema à consideração da agência em contexto. Inf. \& Soc.: Est., v. 23, n. 3, 2013a. Disponível em: $<$ http://www.ies.ufpb.br/ojs2/index.php/ies/article/view/15144>. Acesso em: 10 fev. 2014.

RABELLO, R. Leituras sobre usuário e uso de informação na Ciência da Informação. Perspectivas em Ciência da Informação, v. 18, n. 4, p.152184, out./dez. 2013b. Disponível em:

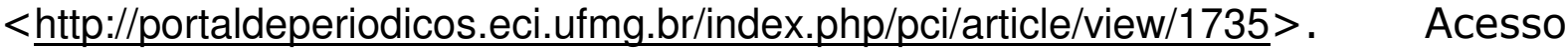
em: 7 jan. 2014.

RABELLO, R.; CAIADO, B. C. Produtos e serviços de informação: estudos de uso e usabilidades. Brasília: IBICT, 2014. Disponível em: <http://livroaberto.ibict.br/handle/1/1058>. Acesso em: 28 nov. 2015.

RABELLO, R.; CAIADO, B. C.; ARAUJO, L. S. Mapeamento de processos do Ibict: macroprocesso gestão de informação: processos dos produtos e serviços da cgpm. [Coord. Maria Carmen Romcy de Carvalho]. Brasília: IBICT, dez. 2013. (Documento técnico, 2a versão).

RIEH, S. Y. Judgment of information quality and cognitive authority in the Web. JASIST, v. 53, n. 2, p. 145-161, 2002.

RIEH, S. Y.; BELKIN, N. J. Understanding judgment of information quality and cognitive authority in the WWW. In: ANNUAL MEETING OF THE AMERICAN SOCIETY FOR INFORMATION SCIENCE, 61., 1998. [S.I.]. Proceedings... [S.I.: s.n.], 1998.

ROCHA, E. C.; SOUSA, M. F. E. Metodologia para avaliação de produtos e serviços de informação. Brasília: IBICT, 2011. 81 p.

SARACEVIC, T. Relevance: a review of and a framework for the thinking on the notion in information science. In: BRAGA, G. M.; PINHEIRO, L. V. R. (Org.). Desafios do impresso ao digital: questões contemporâneas de informação e conhecimento. Brasília: UNESCO; IBICT, 2009. p. 15-70.

WERSIG, G.; WINDEL, G. Information Science needs a theory of 'information actions'. Social Science Information Studies, v. 5, p.11-23, 1985. 